\title{
fjillfsbuth
}

$3 \mathfrak{a m}$

$\mathfrak{v o n}$

\section{Dictar fabidit,}

Dbcronfifforialratbe unb Superintenbenten in Darmffabt.

\section{Giekett.}

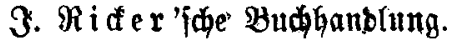

1878. 
